\title{
Craniofacial superimposition studies on a set of Cosimo I de' Medici's (1519-1574) and Eleonora di Toledo's (1522-1562) portraits
}

\author{
Isolina Marota ${ }^{1}$, Cristina Olivieri ${ }^{1}$, Antonio Fornaciari ${ }^{2}$, Stefania Luciani ${ }^{1, *}$
}

\begin{abstract}
A set of portraits of the Florentine grand duke Cosimo I de' Medici (1519-1574) and of his wife Eleonora di Toledo (1522-1562) painted by two major representatives of Florentine Mannerism (Italian Late Renaissance), Pontormo and Bronzino was compared with the skulls of the two subjects utilizing the forensic technique of craniofacial superimposition. The results show that, in the case of Cosimo I, both a painting (Pontormo, workshop of, Cosimo I de' Medici, 1537) and a drawing (Pontormo, Cosimo I de' Medici in Profile, 1537) show lack of fit with the skull in four points (the glabellar outline, the depth of the nasal bridge, the bony lateral wall of the orbit, and the outline of the frontal process of the zygomatic bone). The drawing, therefore, seems to contradict the well established idea that Renaissance painters prepared lifelike sketches of their sitters which were then modified when transferred to the painting. In the case of Eleonora di Toledo, on the other hand, craniofacial superimposition analysis reveals that Bronzino, possibly as the result of a desperate search for the "best angle" of the sitter, adopted an unusual perspective to portray the duchess (Bronzino, Eleonora di Toledo, c. 1539) possibly looking down the sitter, by standing, while the sitter was seated in front of him. The face of the sitter was subsequently, in another painting (Bronzino, Eleonora di Toledo and Her Son Giovanni, c. 1544-45) "transplanted" onto the rest of the body given the impression that the duchess "looks" at the viewer from above.
\end{abstract}

Key Words: craniofacial superimposition, forensic anthropology, skull, face.

$\mathrm{T}$ hetechniques of craniofacialsuperimposition are best known to the public for their forensic applications. The principle of the method is simple. The skull of an individual, whose identity is unknown, is compared with a set of ante-mortem photographs of missing individuals using photographic or electronic video equipment. The careful screening of a set of anthropometrical landmarks which may or may not match in the photographs can allow the examiner to reduce the range of possible identities to a small number or even, under fortunate circumstances, to one [1].
Curiously, as pointed out by Austin-Smith and Maples [2], superimposition methods seem to have been developed, not for forensic applications, but rather with the idea of confirming the identities of historical figures. In 1924, Pearson published a paper describing the comparison of the skull of Robert Bruce, King of Scotland, with engravings and coins depicting the King [3]. Ten years later, the same Pearson, in collaboration with Morant [4], reported on his study of a skull, claimed to be that of Oliver Cromwell, when compared with the bust, masks and painted portraits of the personage. The

1) Laboratory of Molecular Archaeo-Anthropology/Ancient DNA. School of Biosciences and Veterinary Medicine, University of Camerino, Camerino, Italy

* Corresponding author: Laboratory of Molecular Archaeo-Anthropology/Ancient DNA, School of Biosciences and Veterinary Medicine, University of Camerino, Via Gentile III da Varano, 62032 Camerino, Italy, Tel.: 00390737403236 , Fax: 00390737 403290,Email: stefania.luciani@unicam.it

2) Center of Anthropological, Paleopathological and Historical Studies of Sardinian and Mediterranean Populations, Department of Biomedical Sciences, University of Sassari, Sassari, Italy 
head was found to be consistent with life masks and death masks of the English Lord-Protector.

A major conceptual flaw can be found, however, in some pioneer studies, as well as in some presentday ones i.e. pieces of art, either painted portraits or statues, are used as reference effigies to identify a skull of uncertain attribution. There is, for example, the case of a mummified head said to be that of the French king Henry IV, where the purported head is compared with a statue of the king and the (claimed) fit taken as evidence for positive identification [5].

Conversely, there is nothing to prevent one from utilizing the skull of a historical personage to verify whether or not a portrait faithfully reproduces his/her appearance when alive.

To our knowledge, one of the first researchers to use a correct approach in applying skull-face superimposition techniques to cultural artefacts was Frassetto [6]. In his study of the skeleton of the Italian medieval poet Dante Alighieri he compared the calvarium of the poet with a set of portraits, busts and purported death masks. Frassetto was not looking to identify the remains, whose identity was undisputed, but was seeking to determine those, among the numerous effigies of the poet, which best fitted his life appearance.

In recent times, the potential of the craniofacial superimposition approach to solving the issue of 'likeness' in an ancient portrait, and of obtaining clues about the painting techniques of an important Renaissance painter, Tiziano Vecellio ("Titian") has been confirmed by the study of the portrait of Eleonora Gonzaga della Rovere, duchess of Urbino [7].

In 2002 Antonio Paolucci, Superintendent for the Florentine Museums granted permission for the examination of 49 Medici family members buried in the Basilica of San Lorenzo in Florence. The archaeological exploration, conducted between 2004 and 2005 [8] has afforded, among other things, the opportunity to perform craniofacial superimposition studies. The remains of Cosimo I de' Medici and his wife Eleonora di Toledo, already resumed in 1948 by Gaetano Pieraccini, in 2004 were found to be completely skeletonized, in a very well preservation condition, inside two little zinc coffins. The historical sources on the Medici tombs, the epigraphic elements on the graves, metal epigraphs found inside the coffins and of course anthropological studies of the bones allowed to attribute unequivocally the skulls to these historical figures [9].

We present here the results of craniofacial superimposition studies of a set of portraits of the grand duke Cosimo I de' Medici and of his wife, Eleonora di Toledo and show that this technique allows an appreciation of the subtleties and the "tricks of the trade" of two major representatives of the Florentine Mannerism, namely Bronzino and Pontormo.

\section{MATERIAL AND METHODS}

All operations that involved the handling of bones were conducted inside the church of San Lorenzo in Florence in a makeshift laboratory prepared in the socalled Cappella dei Lorena (Chapel of the Lorrainers), this was because the research team was not allowed to move the remains, which furthermore, had to be reburied within two weeks of opening the tombs. Craniofacial superimpositions were performed by a digital camera (Canon EOS 300D) mounted on a tripod and connected to a portable computer (Hewlett-Packard Pavillon). The skulls, with dowels inserted in the auditory meatus, were put on a support placed approximately $3 \mathrm{~m}$ from the camera and photographed from different angles using telephoto lenses. Digital pictures of the skulls were

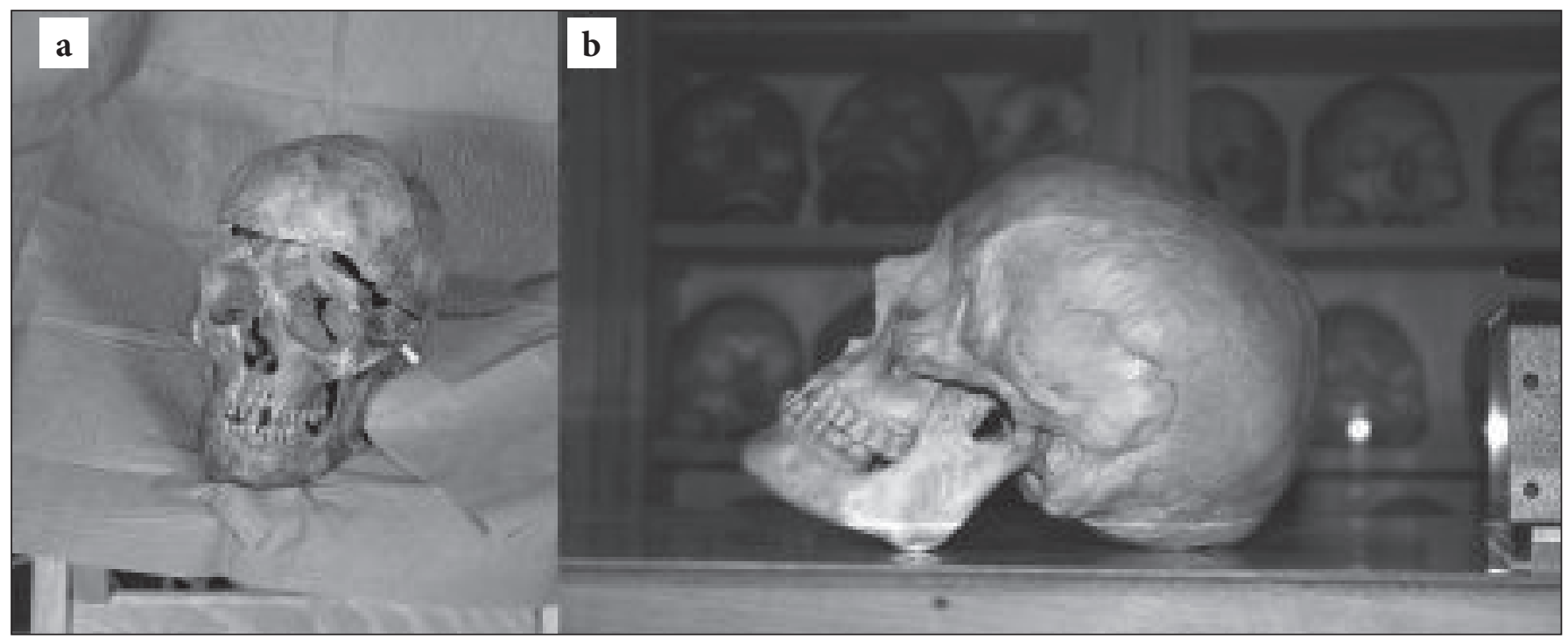

Figure 1. (a) The skull of Cosimo I de' Medici photographed during the exploration of the Church of San Lorenzo in Florence. The skull shows craniotomy obtained with a bone saw [8]. (b) The plaster mould of the skull of Cosimo I de' Medici, 1948, Museo Nazionale di Antropologia, Florence, no. 6368/00. Note that the craniotomy has been hidden. 
superimposed on the portraits using Adobe Photoshop Elements 2.0. The pictures of the skulls were pasted onto those of the portraits and their opacity reduced to approximately $50 \%$ of the original. At this point, the dimensions of the skulls were modified, keeping their relative proportions constant, to fit the portraits. The best fits were obtained by repeating the shot from different angles until a satisfactory result was obtained. Superimpositions were subsequently evaluated in the laboratory using the requirements for consistent fit between skull and face proposed by Austin-Smith and Maples [2]. They are based on a grid of 12 landmarks in lateral view and other 12 in frontal view.

In the case of the skull of Cosimo I, once the remains had been reburied, we realized that the set of photographs we had taken was not sufficient. Fortunately, we could take advantage of a plaster mould, kept at the National Museum of Anthropology in Florence. This, and other moulds, were made in the years 1948 and 1949 following the archaeological exploration of the Cappelle Medicee by Gaetano Pieraccini.

\section{RESULTS}

\section{Cosimo I de’ Medici}

The plaster mould of skull of Cosimo I (Fig. 1 a, b) was first compared with the portrait of the duke attributed to the workshop of Pontormo and kept at the Galleria Palatina in Florence (Fig. 2) using the criteria

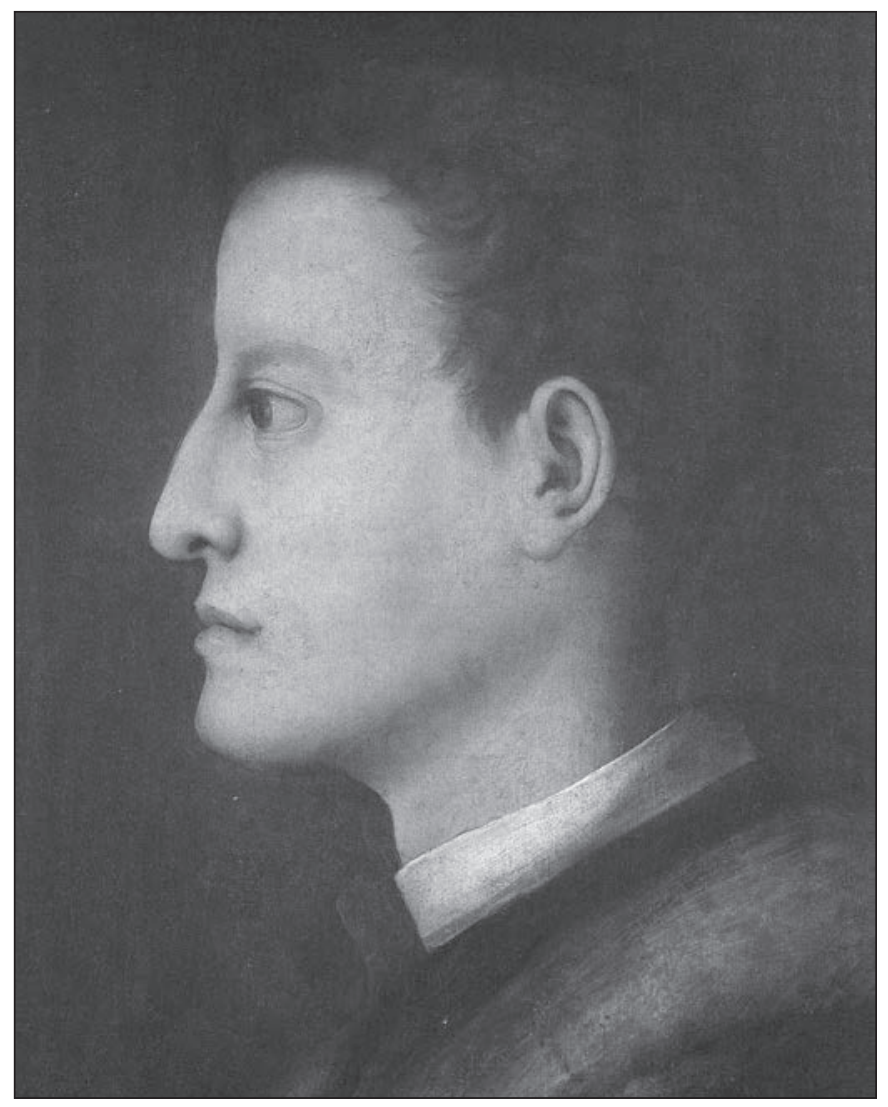

Figure 2. Pontormo, workshop of, Cosimo I de’ Medici, 1537. Oil on panel $(47.5$ x $31.2 \mathrm{~cm})$. Florence, Galleria Palatina. proposed by Austin-Smith and Maples for lateral view comparisons [2].

There is good match in 7 out of 12 points considered, 1 uncertain match (the porion region) while 4 other points (the glabellar outline, the depth of the nasal bridge, the bony lateral wall of the orbit, and the outline of the frontal process of the zygomatic bone) do not fit (Fig. 3 and Table 1).

The superimposition of the skull to the black chalk drawing of the Gabinetto Disegni e Stampe degli Uffizi (Fig. 4), shows basically the same results (Fig. 5).

\section{Eleonora di Toledo}

The skull of Eleonora di Toledo (Fig. 6) was compared with the Bronzino portrait of the duchess kept at the National Gallery, Prague (Fig. 7).

To evaluate the match between skull and face (Fig. 8a) we followed the guidelines of Austin-Smith and Maples for frontal view comparisons [2]. The results are displayed in Table 2.

One can observe that skull and face show a consistent fit in the areas of particular importance for comparison in frontal view such as orbital size and shape, breadth of the nasal bridge, width of the nasal aperture, total facial length and width, ratio of mid-face to upper or lower face length, and mandibular shape. The only exception concerns the external auditory meatus opening that lies in front of the tragus instead of being posterior.

This fit, however, can be obtained with the skull

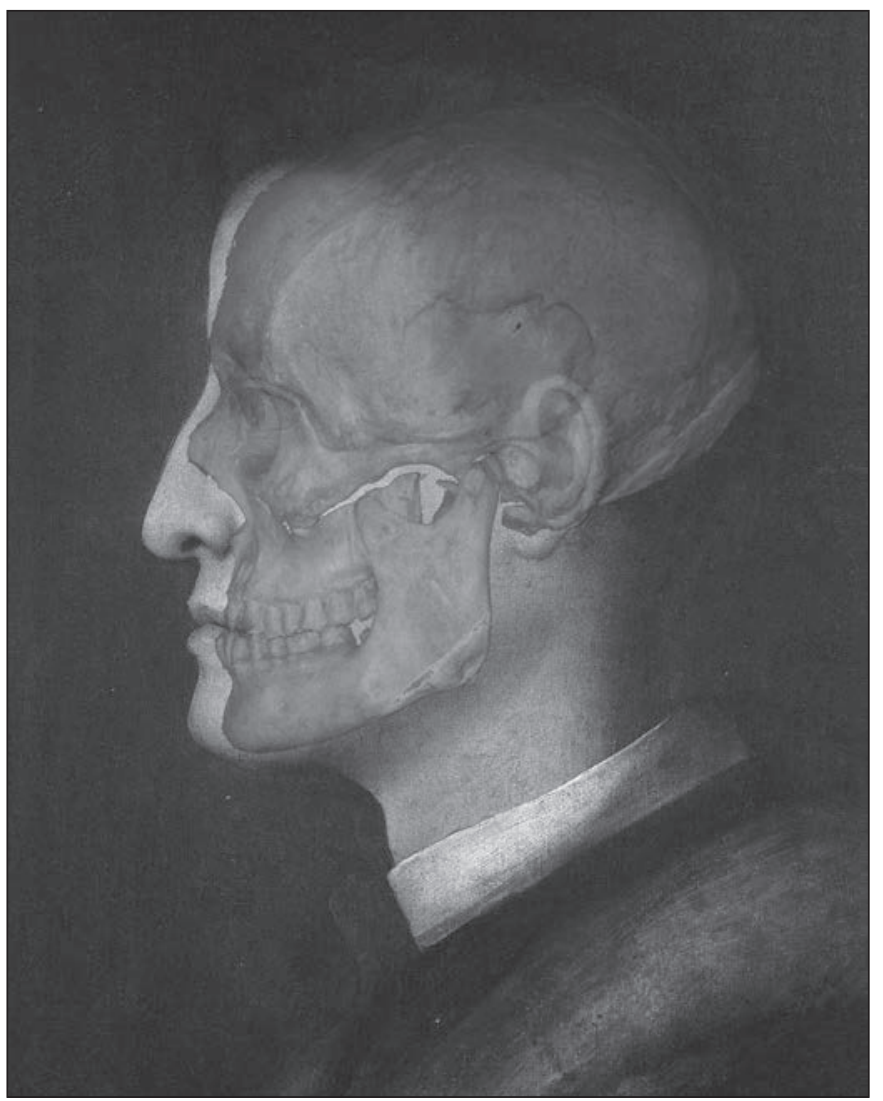

Figure 3. Superimposition of the skull (plaster mould) of Cosimo I de' Medici to the painted portrait by Pontormo. 


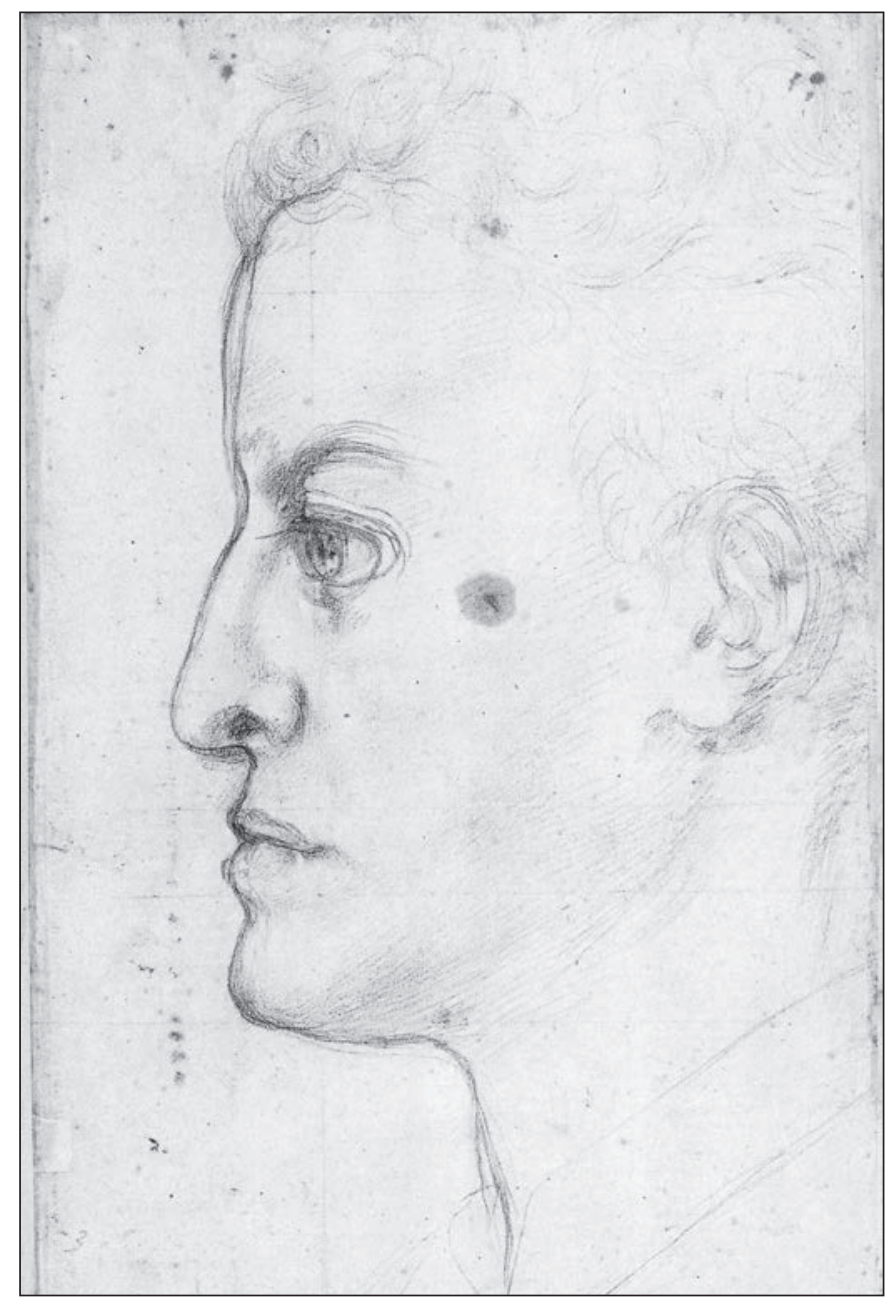

Figure 4. Pontormo, Cosimo I de' Medici in Profile, 1537. Black chalk $(42,1 \times 21,5 \mathrm{~cm})$. Florence, Gabinetto Disegni e Stampe degli Uffizi, no. 6528 verso.

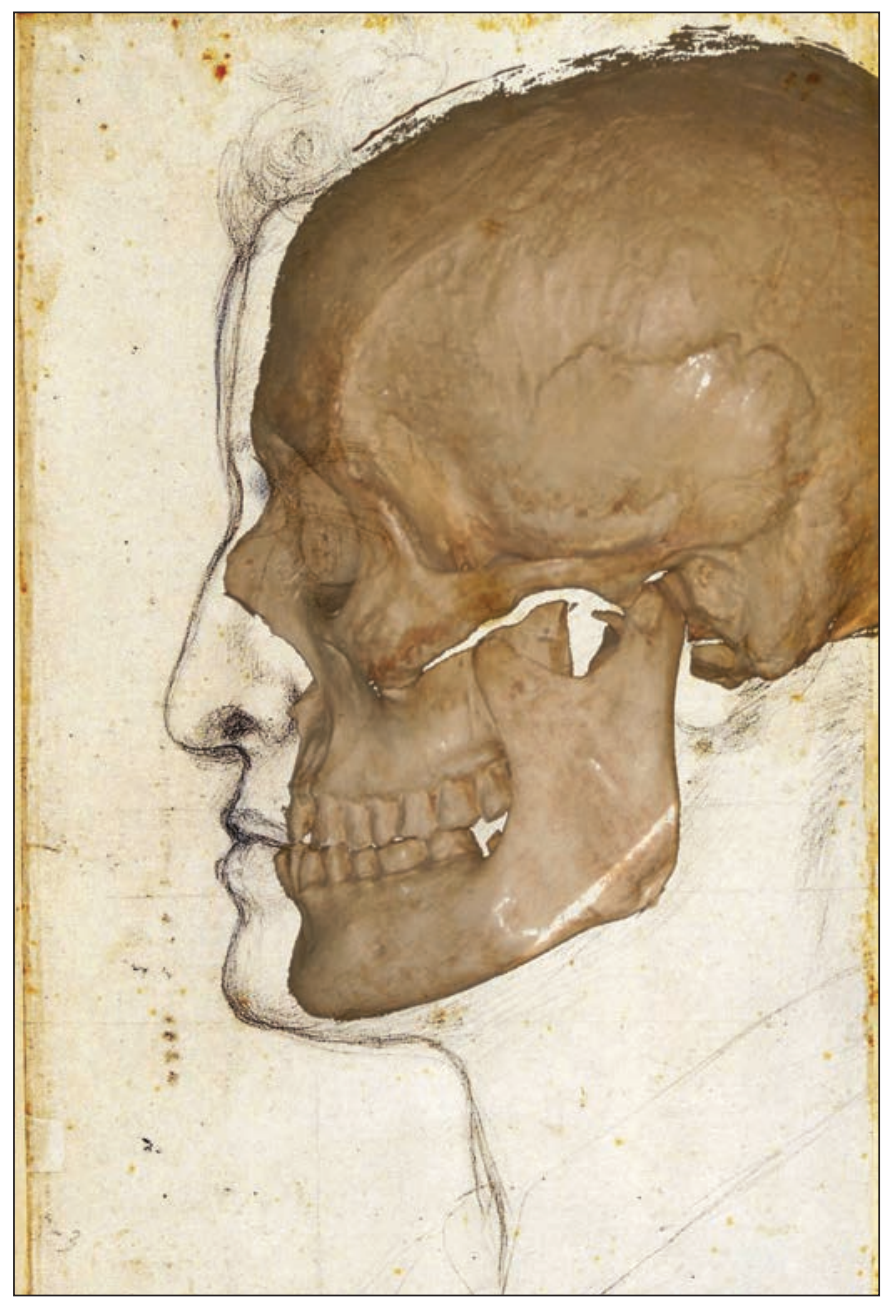

Figure 5. Superimposition of the skull (plaster mould) of Cosimo I de' Medici to the drawing by Pontormo.

Table 1. Comparative examination of the skull of Cosimo I de' Medici and his painted portrait by Pontormo following Austin Smith and Maples' rules (lateral view) for consistent fit between skull and face [2].

\begin{tabular}{|c|c|c|}
\hline No. & Relationship between specific bony areas and surrounding soft tissues & Results* \\
\hline 1 & The vault of the skull and the head height must be similar. & + \\
\hline 2 & $\begin{array}{l}\text { The glabellar outline of both the bone and the soft tissue must have a similar slope although the line of } \\
\text { the face does not always follow the line of the skull exactly. }\end{array}$ & - \\
\hline 3 & The lateral angle of the eye lies within the bony lateral wall of the orbit. & - \\
\hline 4 & $\begin{array}{l}\text { The glabella, nasal bridge, nasal bone area is perhaps the most distinctive. The prominence of the } \\
\text { glabella and the depth of the nasal bridge are closely approximated by the soft tissue covering this area. } \\
\text { The nasal bones fall within the structure of the nose. }\end{array}$ & - \\
\hline 5 & $\begin{array}{l}\text { The outline of the frontal process of the zygomatic bones can normally be seen in the flesh of the face. } \\
\text { The skeletal process can be aligned with the process seen in the face. }\end{array}$ & - \\
\hline 6 & $\begin{array}{l}\text { The outline of the zygomatic arch can be seen and aligned in those individuals with minimal soft tissue } \\
\text { thickness. }\end{array}$ & + \\
\hline 7 & $\begin{array}{l}\text { The anterior nasal spine lies posterior to the base of the nose near the most posterior portion of the } \\
\text { lateral septal cartilage. }\end{array}$ & + \\
\hline 8 & The porion aligns just posterior to the tragus, slightly inferior to the crus of the helix. & $+/-$ \\
\hline 9 & The prosthion lies posterior to the anterior edge of the upper lip. & + \\
\hline 10 & $\begin{array}{l}\text { The pogonion lies posterior to the indentation observable in the chin where the obicularis oris muscle } \\
\text { crosses the mentalis muscle. }\end{array}$ & + \\
\hline 11 & $\begin{array}{l}\text { The mental protuberance of the mandible lies posterior to the point of the chin. The shape of the bone } \\
\text { (pointed or rounded) corresponds to the shape of the chin. }\end{array}$ & + \\
\hline 12 & $\begin{array}{l}\text { The occipital curve lies within the outline of the back of the head. This area is usually covered with hair } \\
\text { and the exact location may be difficult to judge. }\end{array}$ & + \\
\hline
\end{tabular}

${ }^{*}+$, Match found; +/-, uncertain match; -, match not found; n.t., not tested. 


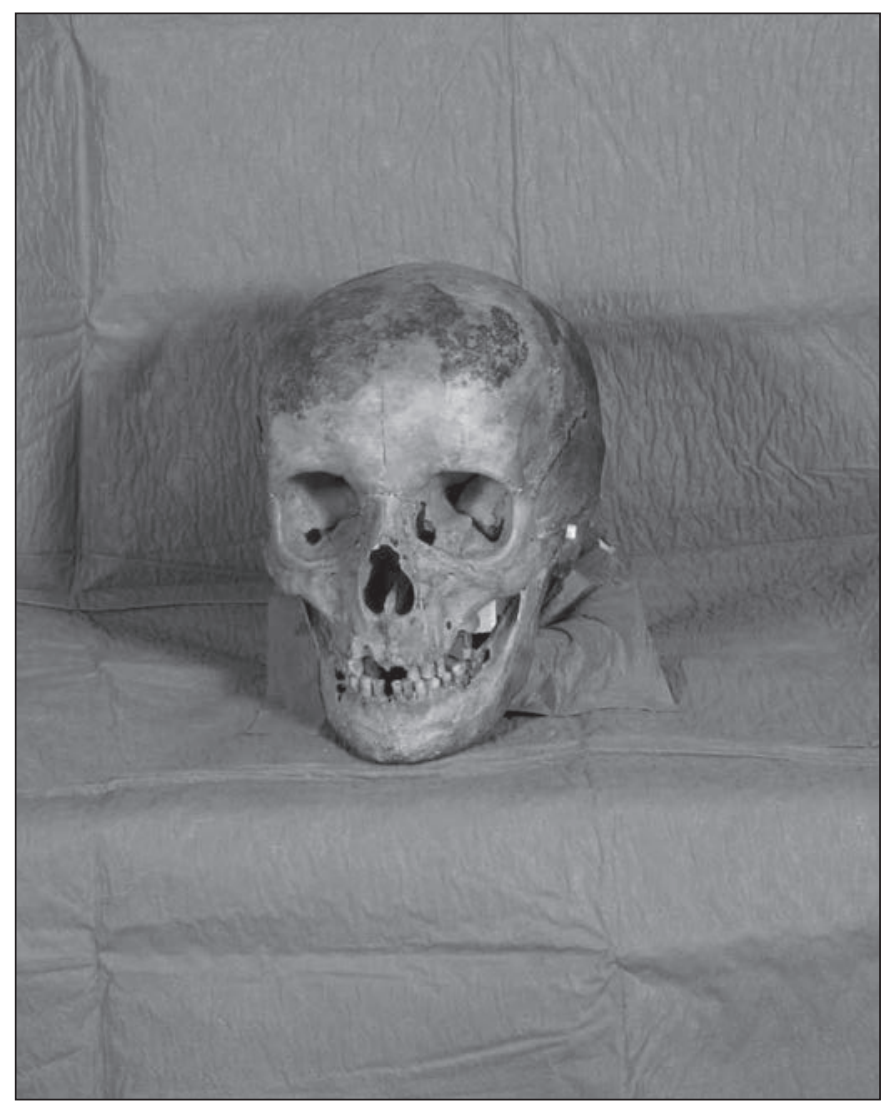

Figure 6. The skull of Eleonora di Toledo photographed during the exploration of the church of San Lorenzo in Florence.
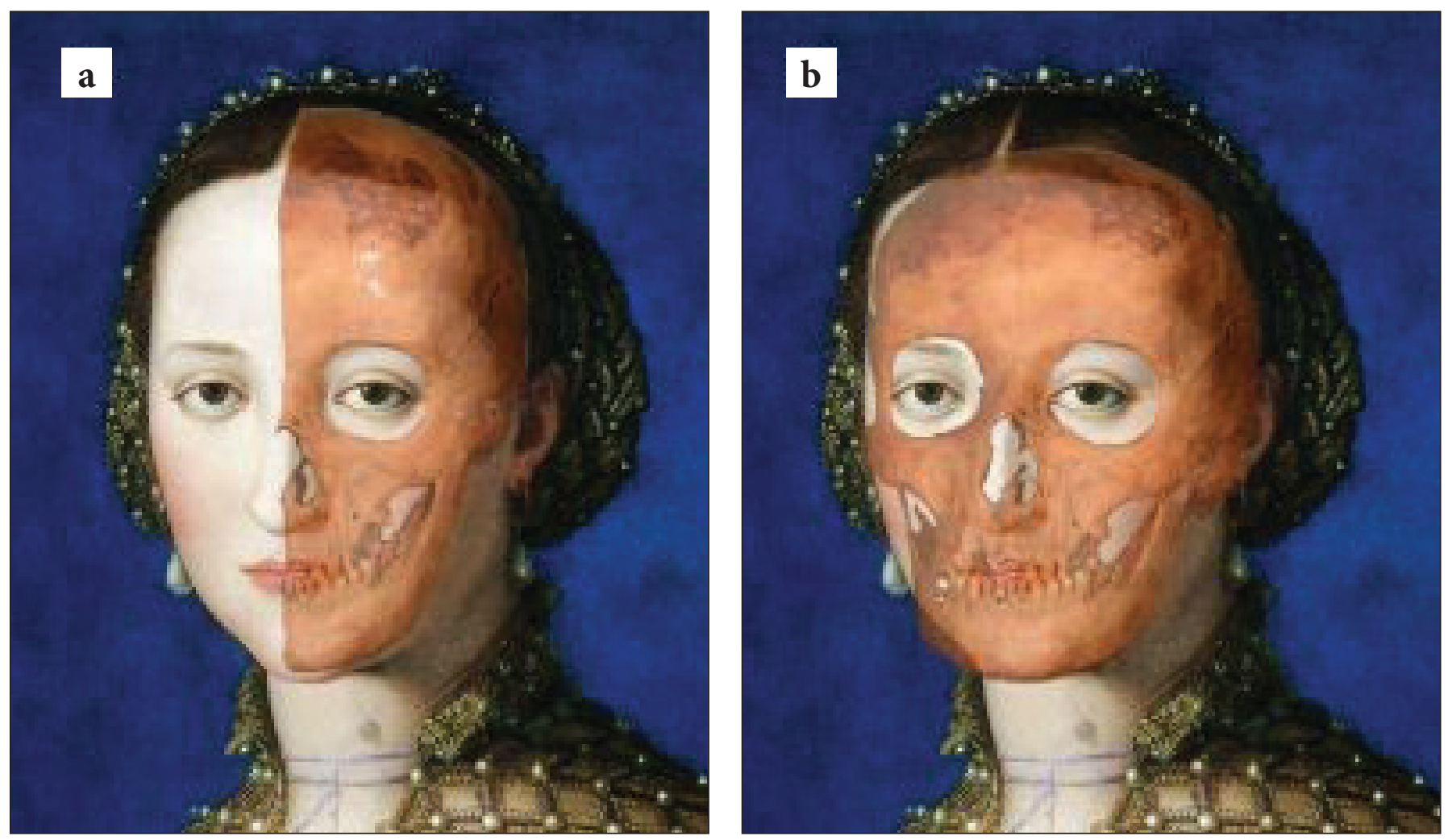

Figure 8. (a) Split-face superimposition of the skull of Eleonora di Toledo to her portrait (Bronzino). The camera is kept higher than the skull. (b) Superimposition of the skull of Eleonora di Toledo to her portrait (Bronzino). The camera is kept at the same level as the skull. 
Table 2. Comparative examination of the skull of Eleonora di Toledo and her portrait by Bronzino following Austin Smith and Maples' rules (frontal view) for consistent fit between skull and face [2].

\begin{tabular}{|c|c|c|}
\hline No. & Relationship between specific bony areas and surrounding soft tissues & Result* \\
\hline 1 & The length of the skull from bregma to menton fits with the face. Bregma is usually covered with hair. & + \\
\hline 2 & The width of the cranium fills the forehead area of the face. & + \\
\hline 3 & $\begin{array}{l}\text { The temporal line can sometimes be distinguished on the photograph. If so, the line of the skull } \\
\text { corresponds to the line seen on the face. }\end{array}$ & n.t. \\
\hline 4 & $\begin{array}{l}\text { The eyebrow generally follows the upper edge of the orbit over the medial two-thirds. At the lateral } \\
\text { superior one-third of the orbit the eyebrow continues horizontally as the orbital rim begins to curve } \\
\text { inferiorly. }\end{array}$ & + \\
\hline 5 & The orbits completely encase the eye including the medial and lateral folds. & + \\
\hline 6 & $\begin{array}{l}\text { The lacrimal groove can sometimes be distinguished on the photograph. If so, the groove observable on } \\
\text { the bone aligns with the groove seen on the face. }\end{array}$ & + \\
\hline 7 & The breadth of the nasal bridge on the cranium and surrounding soft tissue is similar. & + \\
\hline 8 & The external auditory meatus opening lies medial to the tragus of the ear. & - \\
\hline 9 & The width and length of the nasal aperture falls inside the borders of the nose. & + \\
\hline 10 & The anterior nasal spine lies superior to the inferior border of the medial crus of the nose. & + \\
\hline 11 & $\begin{array}{l}\text { The oblique line of the mandible (between the buccinators and the masseter muscles) is sometimes } \\
\text { visible in the face. The line of the mandible corresponds to the line of the face. }\end{array}$ & + \\
\hline 12 & $\begin{array}{l}\text { The curve of the mandible is similar to that of the facial jaw. At no point does the bone appear to project } \\
\text { from the flesh. }\end{array}$ & + \\
\hline
\end{tabular}

${ }^{\star}+$, Match found; +/- uncertain match; - match not found; n.t., not tested.

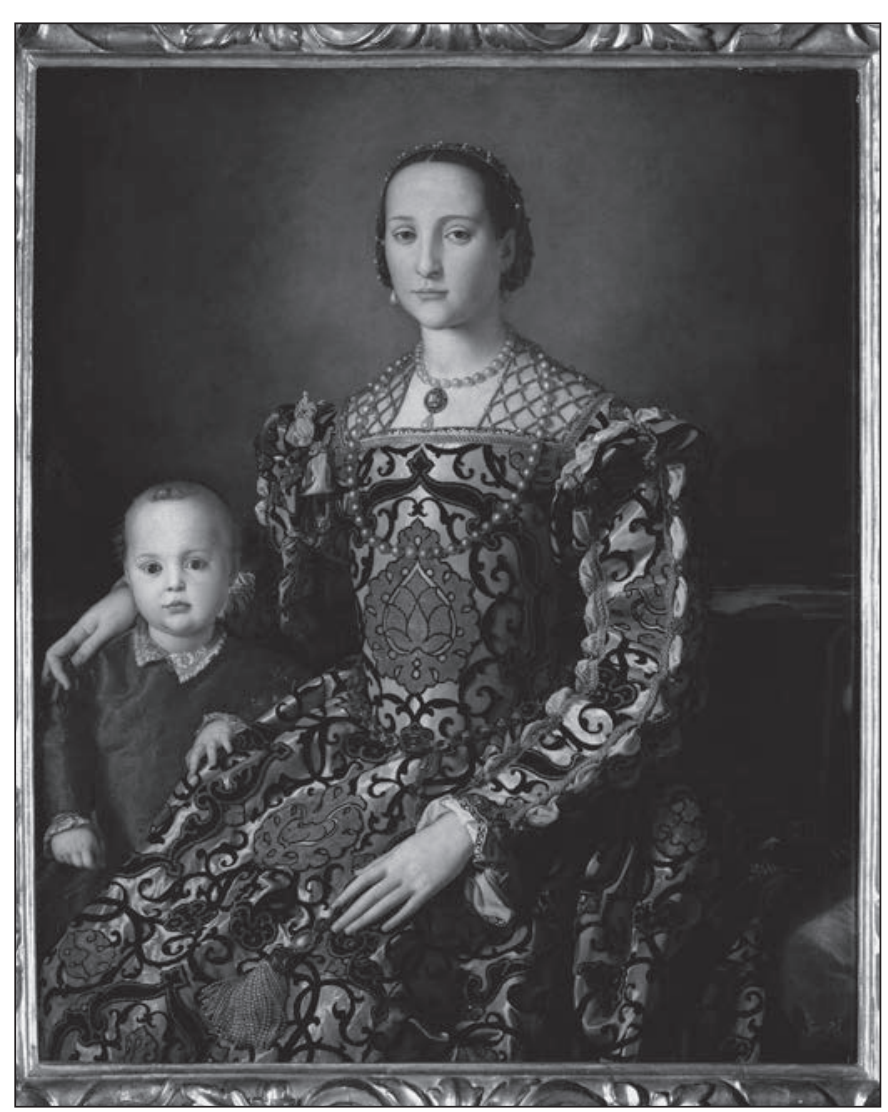

Figure 9. Bronzino, Eleonora di Toledo and Her Son Giovanni, c. $1544-45$. Oil on panel $(115$ x $96 \mathrm{~cm})$ Florence, Galleria degli Uffizi, no. 748 .

kept in the Frankfurt plane and the camera mounted on a tripod higher than the skull's support so that the lenses point downwards to form an angle of approximately $30^{\circ}$ with the floor. On the other hand, when the camera is kept at the same level of the skull, the mandible looks wider and heavier, the bone projects from the flesh. The fit between face and skull becomes lost also at other points (Fig. 8b).

\section{DISCUSSION}

The senior branch of the Medici family was that of Lorenzo il Magnifico (1446-1492), while the junior branch, that of the grand dukes of Tuscany, began with Giovanni delle Bande Nere (1498-1526) and ended with Gian Gastone (1671-1737), the last grand duke. As son of Giovanni delle Bande Nere, Cosimo was a member of the cadet branch [10]. Following the murder of the duke Alessandro by his cousin Lorenzino de' Medici on the night of January 5/6,1537, Cosimo himself became duke. He then became a sophisticated patron of the arts and used them to promote his image as a ruler. In 1539 he married the daughter of Don Pedro, Charles V viceroy in Naples, Eleonora di Toledo. Eleonora participated in the government of Florence and Tuscany and closely oversaw the commissions given to artists. The great portrait painters Agnolo di Cosimo di Mariano Tori (1503 - 1572), better known as Bronzino, and Jacopo Carucci (1494 1556/7), a.k.a. Pontormo, sought new ways of portraying the Florentine men and women through the paintings and drawings they created over the course of two and half decades. Eventually they established a portrait prototype for the patrician and ruling classes [11]. Pontormo is as well known today for his virtuoso drawings as for his finished portraits.

According to art textbooks, the meeting between painter and client, in the case of portraits, gave the former the opportunity to prepare the most accurate and lifelike drawing possible, which was subsequently reinterpreted during its transposition into a painting [12]. It is interesting to note that long before the introduction, 
at the end of XVI century, of small portable darkrooms by Giambattista della Porta, simple devices were available to the painters for the purpose of rapidly and faithfully reproducing the subject. For example, an important piece of equipment in the Renaissance painter's studio was a sheet of glass divided into squares onto which the contour of the sitter could be outlined. The painter sighted the sitter through a hole at the end of a short pole. Subsequently, the draft was transferred to the surface of the canvas. In this way, the principles of central perspective were applied as described by Leon Battista Alberti [13].

A frequently reported example to show that the primary sketch faithfully depicted the subject is the portrait of cardinal Niccolò Albergati by Jan van Eyck. The comparison of the final painting (1431, oil on panel, Kunsthistorisches Museum, Vienna) with a preliminary drawing (1431, silver point, Staatliche Kunstsammlungen, Dresden) shows that the artist has modified the shape of the forehead of the sitter, making it more vertical and higher, and, through a masterly use of the chiaroscuro, modified the width of the left cheek-bone. As a result of these and other minor alterations, such as the shape of the nose and the eyebrows, the stance and the expression of the cardinal acquire both solemnity and moral authority. There is a general agreement on the fact that the seventeen or eighteen-year-old Cosimo I de' Medici's portrait is based on Pontormo's drawing in the Gabinetto Disegni e Stampe of the Uffizi. It would seem that this painting was made soon after Cosimo became duke, on January 9, 1537 , and before he grew a beard, probably later that year. It may have served as a model for a more finished portrait or for the sculptors or medallists who needed to portray him [11]. The craniofacial superimposition examination shows several elements of inconsistency between skull and painting, the most relevant difference being in the profile of the forehead, glabella and nasal bridge. Infrared reflectography has demonstrated that the underdrawing closely follows the drawing, which is just a bit smaller than the painting. As for the drawing, according to some art historians its outlines were reinforced and changed slightly, possibly by another artist when it was transferred to the panel. However, Pontormo may have made these changes himself. In addition, ruled lines on the drawing show that each feature of the face was carefully measured [11], possibly for the purpose of a sculpture or coin commission. When compared with the skull of Cosimo, the drawing shows the same lack of fit found for the painting. Thus suggesting that Pontormo started idealizing the portrait of the duke whilst he was laying down the preliminary sketch. We should note that while the outlines of the drawing were reinforced and changed slightly, the changes (pentimenti) do not improve the fit with the skull. Alternatively, we must assume that the drawing of the Gabinetto Disegni e Stampe of the Uffizi is not the preliminary one but rather the result of the transposition and interpretation of a previous, and now lost, drawing. A further explanation to the lack of fit relies on the fact that the portrait of Cosimo was supposedly painted while he was still an adolescent. It is possible that the growth of the facial structure was not yet complete and that, therefore, the forehead was more vertical than would have been found in the mature duke. Since growth patterns change by genetics, nutrition and stress, it is possible that his development was delayed compared to modern standards.

Mannerist portraits by Bronzino are distinguished by an elegant stillness and a meticulous attention to detail which concentrates on rendering the precise pattern and sheen of the rich textiles. As a result, Bronzino is said to have placed an uncommunicative abyss between the subject and the viewer. Eleonora di Toledo's portrait in the Národní Galerie in Prague perfectly fits this idea: the sitter regards the viewer with a cool glance, if at all. The comparison of the face with the skull, however, reveals something unexpected: the fit can be obtained only when the camera is kept higher than the skull. In order to obtain such a result the painter should have been looking down the sitter, for example by standing, while the sitter was seated in front of him. This conclusion seems at first glance surprising, given the impression the painting produces in the viewer i.e. that the duchess "looks" at the viewer from above. Yet, the fact that the viewer looks down the face of the duchess, and not the other way round, is further corroborated by examination of the eyes of the duchess that look upwards as shown by the fact that the white of the sclera can be seen below the iris. In the celebrated portrait of Eleonora di Toledo and her son Giovanni, painted a few years later (1544-1545) and clearly derived from the previous one (Fig. 9), Bronzino, according to all evidence, "transplanted" the head of the duchess onto a body wearing particularly elaborate costume. In this case, the erroneous impression of the duchess "looking down" at the viewer is further enhanced by the pictorial composition based on a triangular or pyramidal shape that places the sumptuous cloth at the base, and the head of Eleonora at the top. One can speculate about the reasons for such a complicated choice of perspective by Bronzino. The most obvious explanation seems to rely on a search for the most flattering angle of the sitter ("best angle"). Portraying the sitter from above would have produced a more gentle-looking jaw than from other angles (we should emphasise that in Bronzino's portraits both females and males frequently exhibit elongated and pointed faces). We can further add that the choice of portraying the sitter from above would have effectively hidden a double chin, though due to the very young age (17 years) of the duchess at the time of the first portrait, a double chin was probably not a problem. 


\section{CONCLUSION}

For the first time, some intriguing iconological details concerning a set of important paintings of the Late Italian Renaissance have been uncovered. The present study offers a further confirmation of the potential of forensic methods to contribute to our understanding the techniques and modus operandi of earlier portrait painters.
Acknowledgment. The authors would like to thank Monica Bietti, Director of the Museo delle Cappelle Medicee, Florence, and Gino Fornaciari, University of Pisa, for giving them the opportunity to participate to the archaeological exploration in the Basilica di San Lorenzo. The authors are also indebted towards Franco Rollo who, with his expertise, helped with this study and the preparation of the paper.

This study was supported by the University of Camerino (Fondo di Ricerca di Ateneo).

\section{References}

1. Glassman DM. Methods of superimposition. In: Taylor KT. editor. Forensic art and illustration. CRC Press LLC, Boca Raton, Florida. 2001. p. 477-498.

2. Austin-Smith D, Maples WR. The reliability of skull/photograph superimposition in individual identification. J Forensic Sci. 1994; 39: 446-455.

3. Pearson K. The skull of Robert the Bruce, king of Scotland. Biometrika. 1924; 16(18): 1274-1329.

4. Pearson K, Morant GM. The Wilkinson head of Oliver Cromwell and its relationship to busts, masks and painted portraits. Biometrika. 1934; 26(3): 1-116.

5. Charlier P, Huynh-Charlier I, Poupon J, Keyser C, Lancelot E, Favier D, Vignal JN, Sorel P, Chaillot PF, Boano R, Grilletto R, Delacourte S, Duriez JM, Loublier Y, Campos P, Willerslev E, Gilbert MT, Eisenberg L, Ludes B, de la Grandmaison GL. Multidisciplinary medical identification of a French king's head (Henri IV). BMJ. 2010; 341: c6805.

6. Frassetto F. Dantis ossa. La forma corporea di Dante, R. Università di Bologna, Istituto di Antropologia, Bologna. 1933.

7. Rollo F, Mascetti M, Cameriere R. Titian's secret: comparison of Eleonora Gonzaga della Rovere's skull with the Uffizi portrait. J Forensic Sci. 2005; 50(3): 602-607.

8. Fornaciari G, Brier B, Fornaciari A. Secrets of the Medici. Archaeology. 2005; 58: 36-41.

9. Fornaciari G, Vitiello A, Giusiani S, Giuffra V, Fornaciari A. The "Medici Project": first results of the explorations of the Medici Tombs in Florence $\left(15^{\text {th }}-18^{\text {th }}\right.$ centuries $)$. Paleopathol Newsl. 2006; 133: 15-22.

10. Sommi-Picenardi G. Esumazione e ricognizione delle ceneri dei principi medicei fatta nell'anno 1857, Processo verbale e note. Archivio Storico Italiano, serie V, 1-2. 1888. p. 5-53.

11. Strehlke CB. Pontormo, Bronzino, and the Medici: the transformation of the renaissance portrait in Florence, Philadelphia Museum of Art, Philadelphia. 2004.

12. Campbell L. Renaissance Portraits. European Portrait-Painting in the $14^{\text {th }}, 15^{\text {th }}$ and $16^{\text {th }}$ Centuries, Yale University Press, New Haven and London. 1990.

13. Alberti LB. De Pictura, liber I Leon Battista Alberti: On Painting. A new translation and critical edition by Rocco Sinisgalli,Cambridge University Press, New York. 2011. 